\title{
SURGERY BOOK DEDICATED TEACHERS AND STUDENTS IN THE IMPLEMENTATION OF BOOKS PERMENDIKBUD NO.21 AND 22 OF 2016 IN BANDUNG PROVINCE JAWABARAT
}

\author{
Yuni Indriyani ${ }^{1}$, Nurul Fazriyah ${ }^{2}$, Tati Heriati ${ }^{3}$ \\ 1,2,3 Universitas Pasundan, Bandung, Indonesia \\ yuniindriyani@gmail.com ${ }^{1}$, nurulfazriyah@gmail.com ${ }^{2}$, tatiheriati@gmail.com ${ }^{3}$
}

\begin{abstract}
Teachers in the curriculum in 2013 in demand to study the handbook issued by the government do with the mapping of indicators and suitability of basic competencies with further indicator adjusted with Permendikbud No. 21 and 22 of 2016. But in fact in the school teachers have not fully used the book as a teacher in the learning process of teachers still feel confused using the book. Problems in this devotion are facing is how to apply the book of teachers and students on their books Permendikbud 21 and 22 of 2016. The purpose of this service is to determine the extent of understanding of elementary school teachers in the implementation of teacher and student books book their Permendikbud 21 and 22 2016. With the surgical book teacher and student books teachers can better understand how a book teachers and students should book. This dedication was held in Bandung.
\end{abstract}

Keywords: Book, Curriculum 2013, Sweets 21 and 22.

\section{A. Introduction}

This service issues triggered by the awareness of the urgency of upgrading the quality of education through the improvement of the quality of the learning process is an educational innovation that should be done. One innovation is changing the paradigm of learning, of learning centered on the teacher to the studentcentered learning.

Student book is a book that is used by students as a source of learning. This book outlines the minimal effort a student must do to achieve the expected competencies. The role of teachers is very important to improve and adjust the absorption of students by the willingness of activity on students' books.

Book teacher and student book is a book that prepared the government in order to implement the curriculum of 2013. books and books student teacher collated by various stakeholders under the coordination of 
the Ministry of education and culture and used in the early stages of the implementation of the curriculum of 2013. In order to support the successful implementation of the curriculum in 2013 book teacher and student books constantly improved and updated, and updated in accordance with the dynamic needs and changing times. Input from all walks of life are expected to improve the quality of that book. Book is a source of learning have a very large role in the process learning (Kurniasari, 2014: 6).

In the world of books education is needed as a means of development of science and technology. The book is a tool that plays an important role in the learning process. the book itself can not be separated from education, because the media's books as learning resources as well as textbooks or textbook is capable of transferring knowledge or value of life associated with basic competencies that are taught. Student book is a book intended for students who are used to guide the learning activities to help students master certain competencies. Books students not only reading, but also used to carry out the activities in the learning process (activities based learning) it is designed and equipped with examples of the activity sheets in order to learn something relevant to the life that happened, the book students at interchanges to facilitate students get meaningful learning experiences (Kemendikbud: 2014: 3).

Student books and teacher guide outlines the minimal effort a student must do to achieve the expected competencies. Book teacher and student book is a unity that can not be separated, meaning that when teachers use students 'books for learning purposes learners then it was also a teacher requires teachers books that will be made as guidelines in utilizing the students' books. This means that the teacher used the book sbagai explanation of the activities that should be done at the student book.

Problems in Cluster $34 \mathrm{sub}$ districts Batununggal, Implementation books and books teachers in primary school students have not been fully effective and many teachers and students who feel complained to the application of the book. Therefore, Devotion this book review is a way to understand the teachers 'understanding of teachers and students' books books 
in accordance with Permendikbud No. 21 and 22, 2016. Seeing the importance of book teacher and student books for all the teachers and the dedication will be held a book review teacher and guide students in applying Permendikbud No 21 and 222016 on content standards primary and secondary education and the standard of the primary and secondary education in Cluster 34 subdistricts Batununggal Bandung. With the book review are expected teachers can better understand the book teacher and student book on permbaharuan of Permnendikbud 2016.

\section{B. Method of Implementation}

The method used in this dedication to the community using surgical training guide teachers and students in permendikbud books 21 and 22, 2006 for teachers in the District 34 Batununggal Force.

There are four steps involved in faculty dedication to the community, namely, observation to look at the problem and retrieve the data in the cluster 34 Batunungggal District of the city of Bandung, the implementation of surgical training teachers and student books book in permendikbud No. 21 and 22, 2006, participants in this training are teachers of elementary school groups 34 subdistricts Batununggal consisting of 5 schools, the method used in this implementation is a lecture, discussion, question and Java and the practice of analyzing a book teacher and student books according to class of teaching.

\section{Result and Discussion}

Briefly and clearly describe the results obtained and fitted with a discussion that explores the results of the implementation of activities. Based on the results of preliminary observations, the team of devotion found some things that become a problem to the teacher, the teacher discovered discrepancies teacher book material with students' books. So that the material provided is not maximal. This suggests that this workshop is very important to be implemented.

Implementation of community service activities through several stages of them, observations were made on Tuesday, September 5, 2017. 
These observations are conducted to find out about school data on the cluster 34, and learning, curriculum and assessment used by teachers in learning. Conducting a book review workshop teacher and student books in permendikbud No. 21 and 22, 2016 was conducted on Monday, 16 October 2016.

Beginning at 08:00 hours till 17:00, consisted of two sessions. The first session delivered material explanation of permendikbud 21 and 22, 2016, at this session participants will understand about the content standards which contain a level of competence and core competencies that include spiritual attitudes, social attitudes, knowledge, skills, and standardized process. carrying out learning in the educational unit to achieve competency standards, so that the educational units should be organized in a way fun, challenging, motivating the students to actively participate and provide space for creativity, according to their talents, interests, and psychology students.

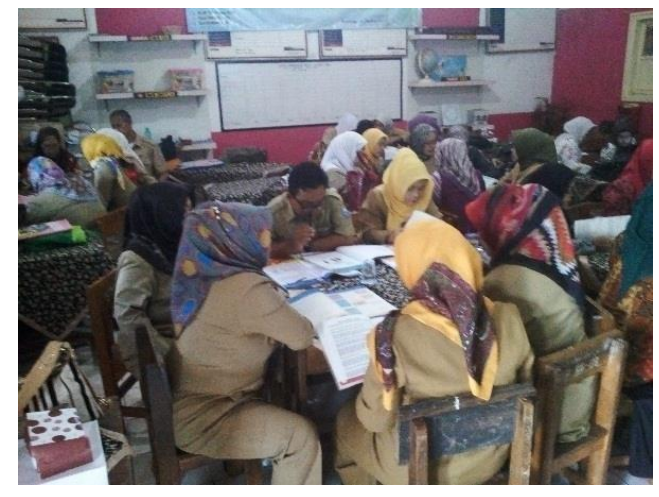

Figure 1. Session 1 Permendikbud 21 and 22, 2016

The second session presenting the material to analyze a book teachers and students' books, teachers in the 12 groups according to the grade of teaching and assigned to analyze a book teacher and student books.

In this activity the participants were very enthusiastic because teachers find inequality of material contained in the book teacher and student books. Seen from a book teacher competence, indicators, adapted to the material in the student book. Teachers active in asking about what they found in the book of teachers and students' books. 


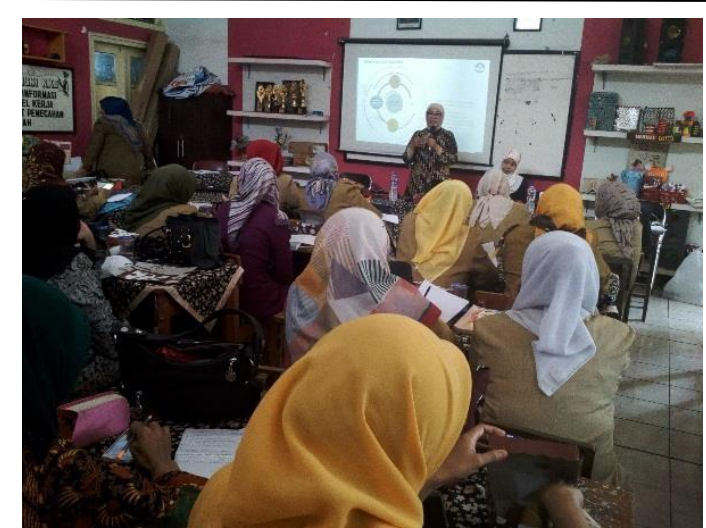

Figure 2. Session 2 Analysis Books Teacher And Student Book

Based on the results of field participants turned out to be enthusiastic teachers during the workshops, workshop materials is felt is necessary for the participants for discussing policies related to the policies of permendikbud in developing content standards and standards in accordance with the process yag learners. The workshop participants also seen very active in the process of the workshop. They are keen to practice analyzing a book teachers and students based on the analysis of books are still many discrepancies, the teachers guide the basic competencies and indicators in line with the theme, but the students' books are not visible material in accordance with the basic competencies and indicators contained in the book the teacher. Actively them dared to ask, in cooperation with the group.

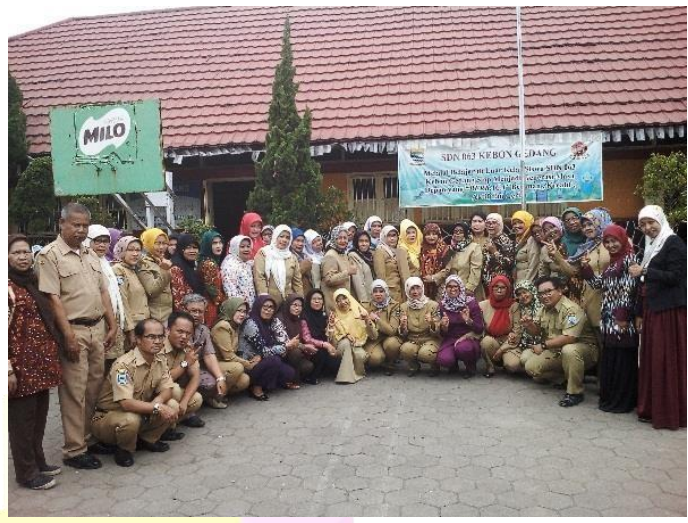

Figure 3. Photos Joint Workshop

So we can conclude that this workshop is in need of teachers, especially in the group of teachers in the District 34 Batununggal Bandung.

\section{Conclusion}

Community service activities is largely planned in the proposal can be implemented. Teachers at the workshop very much alive, so also when analyzing a book teacher and student books, the implementation of such devotion has never done so they requested a workshop was held back.

Implementation of the Cluster service in the District 34 Batununggal Bandung felt by the team and the participants were very satisfactory, 
judging from indicators of enthusiastic

participants who attended the

workshop from beginning to end.

Given the magnitude of the benefits of this public service activities, activities of this community services do similar activities just a different target and place and a wider range of schools,

\section{REFERENCES}

Imas, Kurniasih. (2014). Text Books. Surabaya: Said Pena.

Kemendikbud. (2013). Understanding the Student Book And Book Teacher Primary Schools Learning. Jakarta: Kemendikbud.

Kemendikbud. (2016). Minister and Culture Regulation No. 21 Year 2016 About the Content Standards. Jakarta: Kemendikbud.

Kemendikbud. (2016). Minister Regulation No. 21 Year 2016 About Standard Process. Jakarta: Kemendikbud.

Mulyasa. (2013). Development and implementation of the curriculum in 2013 Bandung: Remaja Rosdakarya.

Conscience, theresia 2014 Position And Function Of Students And Books Book Guru http://theresianurani.blogspot.c om $/ 2$

014/06/kedudukan-dan--book function-student-dan.html, accessed on Wednesday, January 18, 2016 10:00 Hours. 